\title{
GENDER SENSITIZATION TOWARDS FUTURE GADGETS IN EDUCATION
}

\author{
Sushma Rani \\ Senior Research Fellow (UGC-SRF), Department of Education, \\ Banasthali University, Jaipur, Rajasthan, India.
}

\begin{abstract}
Tomorrow's future is strictly based on today's students. Students are considered as a preliminary basic building block for the construction of huge society. Thus, the student's must be expected to develop good moral skills not only for their basic necessities or requirements but to groom themselves as an essential part of country's economic growth and technological advancements. The task of teacher here plays an important role nomatter whether s/he is a mentor, guider, philosopher, educator or an expert, whose responsibility is not just to inculcate appropriate skills in the minds of students but inside and outside the classroom activities also. The expected future scenario is quite different from the present traditional classroom situation. The classroom does not mean confined only to the four walls of a room, but it should inculcate the use of latest tools, devices and gadgets in modern classroom teaching practices. The paradigm shift has been taken place for the transmission of learning to reshape the classroom for global perspectives in order to fulfill the visions of 2020. The paper has the objective to find out the opinion of students towards utilizing future gadgets that can be used for educational purposes. The findings show that a vast majority of students have positively opined towards utilizing the future gadgets in classroom practices. This study will highlight the student's interest towards global competition in terms of their own standpoint in the world.
\end{abstract}

\section{KEYWORDS}

Educational Technology, Futurology, Future Gadgets, Technological Devices.

\section{INTRODUCTION}

The time is at no more distance when we will be having innovative technologies all around us. The students will be using laptops, e-readers, PDA's, mini tablets etc. engaging in various classrooms practices. The teacher who today used to teach their classroom with traditional teaching techniques and practices will make their classroom teaching more effective and interactive with the help of technological devices and gadgets. But for all this we have to change the present educational system in terms of course curriculum content, teaching strategies, evaluation, assessment, administration and management. Roger Johnson explains, "If we are to teach people to be cooperative, then education and psychology must work together. You see, a typical classroom teacher is taught to keep students quiet and apart, indirectly fostering competition. Yet ....people learn best when they co-operatively with each other. Children who experience this type of learning at an early are carrying it with them as they mature."

DOI : 10.5121/oraj.2015.2401 
Operations Research and Applications : An International Journal (ORAJ), Vol.2, No.4, November 2015

The technological teaching strategies significantly posed some changes in present educational system but not to proper extent to fulfill the process of learning. Not so long ago, the opinions of students about utilizing future gadgets have been studied with respect to learning perspectives in terms of Indian educational scenario. So, enormous efforts have been taken to sustain the technological advancements and growth in terms of teaching-learning process. UNESCO, "Integrating technology into education can help to bring quality education to everyone, everywhere - a key goal of the education for all initiative. The citizens of the future must be equipped with sufficient knowledge with to keep up with technological advances and demands of the $21^{\text {st }}$ century." If we continuously teaching our students the way we taught yesterday, we will not be able to fulfill the visions of 2020. We are not conscious about how to prepare students for today or tomorrow, as today's course-curriculum will shift their vision from learning "know what" to learning "know how " and "know where". Thus it would not be able to imagine a world without having techno-friendly environment and techno-opportunities to change the global perspectives in terms of teaching-learning, cooperative learning, collaborative learning and elearning.

\section{FUTURE TECHNOLOGY}

Information and Communication Technology (ICT) has continuously transforming the status of present educational system. Students are learning at their own pace with the help of computers, laptops, interactive-white boards, simulation devices and mobile phones. In universities and colleges, students are attending various Information Technology (IT) courses, while some are consulting internet for their day-to-day purpose such as searching educational content, answer keys, booking tickets, PowerPoint presentation, research work etc. So the adoption of new technologies changes the current mental set-up educators, learners and various stakeholders by providing them with enormous educational opportunities challenging traditional ways of teaching-learning strategies. Today the trend of "Global Education" takes place. The people of all ages are curious to get knowledge, irrespective of their age to pursue learning at any level. The online learning, e-learning, e-textbooks, e-books, e-readers, PDA's, Smartphone's are becoming adequate of sources of providing knowledge to the whole masses. The latest innovations and new teaching devices are becoming 'Knowledge Window', to educate them with proper learning skills and innovative practices nomatter where one is sitting anywhere in the world. Through globalization of education, the technological fields and innovations are continuously transferring knowledge from Western countries into developing countries results in 'Global Education Society'. This rise of global society indulges students and childrens towards future citizens of the world through technological and communication advancements in order to cope up with the global challenges. The future of our nation strictly depends on "the coming generation's knowledge, skills and the intellectual capacity to meet the challenges of accelerated change and uncertainty."

The current research has shown significantly outcomes about usage of future gadgets that can be incorporated into the classroom teachings and environment. The gadgets such as 3-D devices, Bluetooth devices, 4G-5G technologies, augmented virtual classrooms, high memory storage devices, gesture-based devices, document projectors, and other innovative teaching devices will transformed the traditional classroom into "Future Classrooms". 
Operations Research and Applications : An International Journal (ORAJ), Vol.2, No.4, November 2015

\section{Need for the Study}

Today's world is full of competitions and challenges. Soloway and Prior, 1996; Collis, 2002, "Information and Communication Technology (ICT) is a powerful tool that has changed many aspects of the life we live. Over the past two or three decades, there were gigantic changes occurs in various fields such as business, law, medicine, engineering, I.T., tourism, architecture, travel, agriculture, space. Today the means of operating technology in these fields are vastly different form the techniques they were operated in the past. But we are still lagging behind in the field of education, as the influence of these technologies is still less than the changes occurred in the other fields." So, the various researches are continuously being done in India and neighboring countries to improve the status of education through the use of latest tools, devices and innovative gadgets. Thus the researcher adopted this study to know the sensitization of students that how much aware are they about the use of future technology through the use of future gadgets in education. So, in order to find out the answers of the following questions, the researcher attempted for the present study:

- What can be the possible latest technological devices to be inculcated into the present educational system?

- Are they really be useful or beneficial for our teaching-learning process? If yes, how and in what ways they will incorporate towards best practices in education?

- In what respect these latest technological devices are useful in various domains of education?

- What are the opinions of the students about utilizing future gadgets in education?

- What are the perceptions of students about the usage of future gadgets in educational system?

- What are the perceptions of students regarding barriers about the use of future gadgets that can be used in educational purpose?

- What are the perceptions of students regarding preparatory-needs about the use of future gadgets that can be used in educational purpose?

\section{OBJECTIVES OF THE STUDY}

- To identify the future gadgets that can be used for educational purpose.

- To explore the educational utilization of the future gadgets for educational purpose.

- To analyze the perceptions of student's about utilizing future gadgets for with respect to background variables such as:

$>$ Gender

$>$ Age

$>$ Educational Qualifications

$>$ Streams

- To prepare the roadmap for the future gadgets that can be used in educational purposes.

\section{HYPOTHESES OF THE STUDY}

\section{Research Hypotheses}

$\checkmark \quad$ To identify the future gadgets that can be used in education for students. 
Operations Research and Applications : An International Journal (ORAJ), Vol.2, No.4, November 2015

$\checkmark$ To explore and list out the educational utilization of the future gadgets that can be used in educational purpose.

$\checkmark$ To categorize the use of future gadgets in education on the basis of their educational utilization in education.

$\checkmark$ To analyze the perception of students about the use of future gadgets in education with respect to personal variables such as gender, age, streams and teaching classes.

$\checkmark$ To prepare the roadmap for the future gadgets that can be used in educational purposes.

\section{$>$ Null Hypotheses $(\mathrm{H} 0)$}

$\checkmark$ H01. There is no significant difference in the perceptions among students in education about the utilization of future gadgets in education with respect to the gender.

$\checkmark$ H02. There is no significant difference in the perceptions among students in education about the utilization of future gadgets in education with respect to the age.

$\checkmark$ H03. There is no significant difference in the perceptions among students in education about the utilization of future gadgets in education with respect to the educational qualifications.

$\checkmark$ H04. There is no significant difference in the perceptions among students in education about the utilization of future gadgets in education with respect to the Streams.

\section{OPERATIONAL DEFINITIONS}

FUTURE GADGETS: The Future gadgets referred to all those devices, tools and teaching aids that may not be used in Indian scenario or partly being used as sign of novelty.

EDUCATION: Education may be termed as the process of imparting knowledge and skills for overall development. It may be formal, non-formal, and in-formal education.

UPGRADATION: The process, skill or art of raising or uplifting any situation, phenomenon or activity.

STAKEHOLDERS: The word stakeholders refers to all those who are directly or indirectly involved with the process of education i.e. students, teachers, administrators, principals, gadgetexperts, parents etc.

\section{VARIABLES USED IN THE STUDY}

A concept which can take on different quantitative value is called as a variable. The present research study has two types of variables one is dependent variable and another is independent variable.

Dependent Variables: One variable depends upon the other or is a consequence of the other variable; it is termed as the dependent variable. The dependent variables in this study are the perception of students about the use of future gadgets in education. 
Operations Research and Applications : An International Journal (ORAJ), Vol.2, No.4, November 2015

Independent Variables: The variable that is antecedent to the dependent variable. In the study independent variables are considered in terms of the background variables such as gender, age, stream, and educational qualifications.

\section{DELIMITATIONS}

The present study is limited to one Union Territory i.e. Chandigarh region. Further the study is limited to teachers and educationists teaching in various educational, technical and professional institutions under the colleges, institutes and universities of Chandigarh region.

\section{Statistical DESIGN}

\subsection{Methodology}

The data used for the present study is of "Mixed Method" research based i.e. both quantitative and qualitative in nature. The data has been collected with the help of an opinionnaire scale, which is qualitative in nature. Also, the data obtained in the form of frequency is quantitative in nature. The investigator adopted exploratory survey method to study the present problem. After the selection of the title and the tool, the data were collected from 200 students. The data, thus collected were statistically analyzed and conclusions were drawn. The investigator had taken 4 background variables i.e. gender, age, educational qualifications and streams

\subsection{Population and Sample}

In the present study the population which means the entire number of students and availability of future gadgets in mass media. The sample for the present study consisted of 200 students of Engineering/I.T/Computers, Sciences, and higher educational backgrounds (Engineering, Sciences, Technology, IT, Computers etc.) selected from the Chandigarh region, (U.T.), India. The purposively sampling technique had been adopted to select the adequate sample from the population.

\subsection{Tools and Statistics}

The investigator constructed a self-made tool consisting of opinionnaire scale. Using contentanalysis technique a list of 234 gadgets were identified, categorized and list-out on the basis of 24 categories that was further categorized into various sub categories based on their educational utilizations and implications using content analysis technique. The student's perceptions were analyzed on the basis of the tool consisting of 24 categories of available future gadgets with their specifications and features. Each student has answered 24 categories, thus in overall 200 students responded towards 4800 categories using opinnionaire scale. The Cronbach's Alpha based on standardized item is found to be 0.819. For the present study the following tools used are as follows:-

I. Content Analysis Tables: Data collected from (Newspapers, Internet, Magazines, T.V., Journals, etc.).

II. Perception scale of Students about the use of Future Gadgets in education with respect to background variables. 
Operations Research and Applications : An International Journal (ORAJ), Vol.2, No.4, November 2015

\subsection{Collection of Data and Scoring}

The pilot study has been done on 10 experts of reputed professional and technical institutions of the Chandigarh region, Union Territory. After the modification of the few statements as per the expert's views, the tool was employed on the 200 students of engineering/I.T/Computers, Sciences, and higher educational backgrounds of Chandigarh region, (U.T.). The data thus collected have been scored on the basis of the rating scale based on the three point scale i.e. "Least Relevant", "Relevant", and "Most Relevant", scored as 1, 2, 3 respectively. The test of Independence (Chi-Square), frequency tables and percentage were the statistical techniques used for the study. For the present study the investigator has established the content validity but the reliability of the tool could not be established due to lack of time.

\subsection{Statistics Used}

The Test of Independence (Chi-Square), frequency tables and percentage were the statistical techniques used for the analysis and interpretation of the data.

\section{MAJOR FINDINGS}

The analysis of data collected from the sample leads to the following conclusions:

1. There is no significant difference in the perception of students' about the utilization of future gadgets in education with respect to the gender. (See in Graph No.-1).

2. There is significant difference in the perception of students' about the utilization of available future gadgets in education with respect to the age. (See in Graph No.-2).

3. There is significant difference in the perception of students' about the utilization of available future gadgets in education with respect to the streams. (See in Graph No.-3).

4. There is no significant difference in the educational qualification-wise perception among students about utilizing available future gadgets in education. (See in Graph No - 4).

\section{Table no-1}

\begin{tabular}{|c|c|c|c|c|}
\hline \multirow{2}{*}{$\begin{array}{l}\text { Background } \\
\text { Variables }\end{array}$} & \multicolumn{3}{|c|}{ Gender-Wise (Learning) } & \multirow{2}{*}{ Total } \\
\hline & 1(Least relevant) & 2(Relevant) & 3(Most Relevant) & \\
\hline MALE & $\begin{array}{l}309 \\
325.88 \\
(0.87)\end{array}$ & $\begin{array}{l}607 \\
571.57 \\
(2.20)\end{array}$ & $\begin{array}{l}980 \\
998.56 \\
(0.34)\end{array}$ & 1896 \\
\hline FEMALE & $\begin{array}{l}516 \\
499.12 \\
(0.57)\end{array}$ & $\begin{array}{l}840 \\
875.43 \\
(1.43)\end{array}$ & $\begin{array}{l}1548 \\
1529.44 \\
(0.23)\end{array}$ & 2904 \\
\hline Total & 825 & 1447 & 2528 & 4800 \\
\hline
\end{tabular}


Operations Research and Applications : An International Journal (ORAJ), Vol.2, No.4, November 2015

* Expected values are displayed in italics

* Individual $\chi^{2}$ values are displayed in (parentheses)

Graph-1:- Test of Independence between (Chi-Square)-Gender-Wise perceptions of students about the use of available Future Gadgets in education.

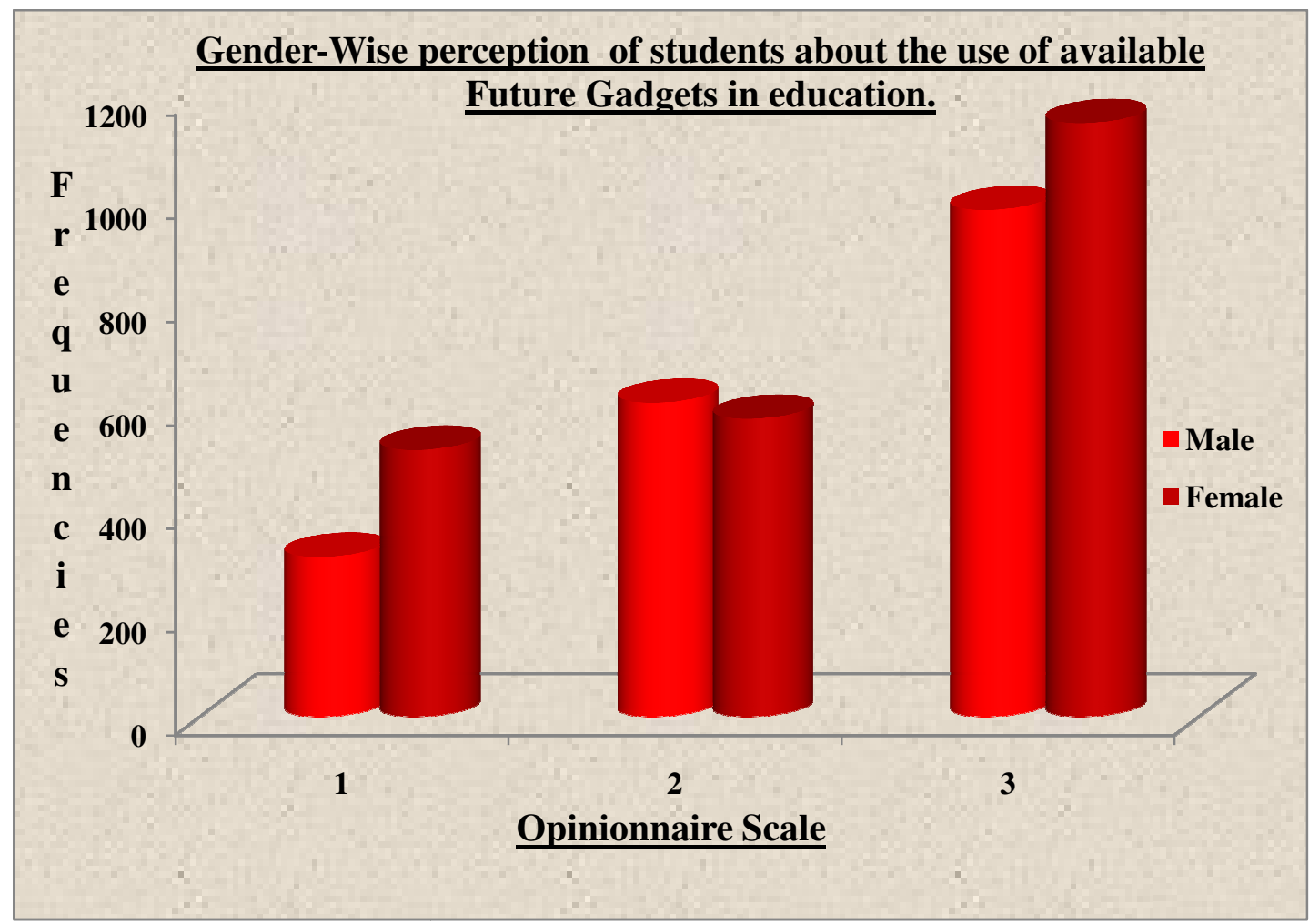

Table no-2

\begin{tabular}{|c|c|c|c|c|}
\hline \multirow{2}{*}{$\begin{array}{l}\text { Background } \\
\text { Variables }\end{array}$} & \multicolumn{3}{|c|}{ Age -Wise(Learning) } & \multirow{2}{*}{ Total } \\
\hline & 1 (Least relevant) & 2(Relevant) & 3(Most Relevant) & \\
\hline Below 20 Yrs & $\begin{array}{c}306 \\
338.66 \\
(3.15)\end{array}$ & $\begin{array}{c}630 \\
594.50 \\
(2.12)\end{array}$ & $\begin{array}{c}1032 \\
1034.84 \\
(0.01)\end{array}$ & 1968 \\
\hline$(21-30)$ Yrs & $\begin{array}{c}488 \\
470.82 \\
(0.63)\end{array}$ & $\begin{array}{c}791 \\
826.50 \\
(1.52)\end{array}$ & $\begin{array}{c}1457 \\
1438.68 \\
(0.23)\end{array}$ & 2736 \\
\hline Above 30 Yrs & $\begin{array}{c}32 \\
16.52 \\
(14.51)\end{array}$ & $\begin{array}{c}29 \\
29.00 \\
(0.00)\end{array}$ & $\begin{array}{c}35 \\
50.48 \\
(4.75)\end{array}$ & 96 \\
\hline Total & 826 & 1450 & 2524 & 4800 \\
\hline
\end{tabular}


Operations Research and Applications : An International Journal (ORAJ), Vol.2, No.4, November 2015

$$
\chi^{2}=26.915, \quad \text { df }=4, \quad \chi^{2} / \mathrm{df}=6.73, \quad \mathrm{P}\left(\chi^{2}>26.915\right)=0.0000
$$

* Expected values are displayed in italics; * Individual $\chi^{2}$ values are displayed in (parentheses)

Graph-2:- Test of Independence (Chi-Square) - Age-Wise perceptions of students about the use of available Future Gadgets in education.

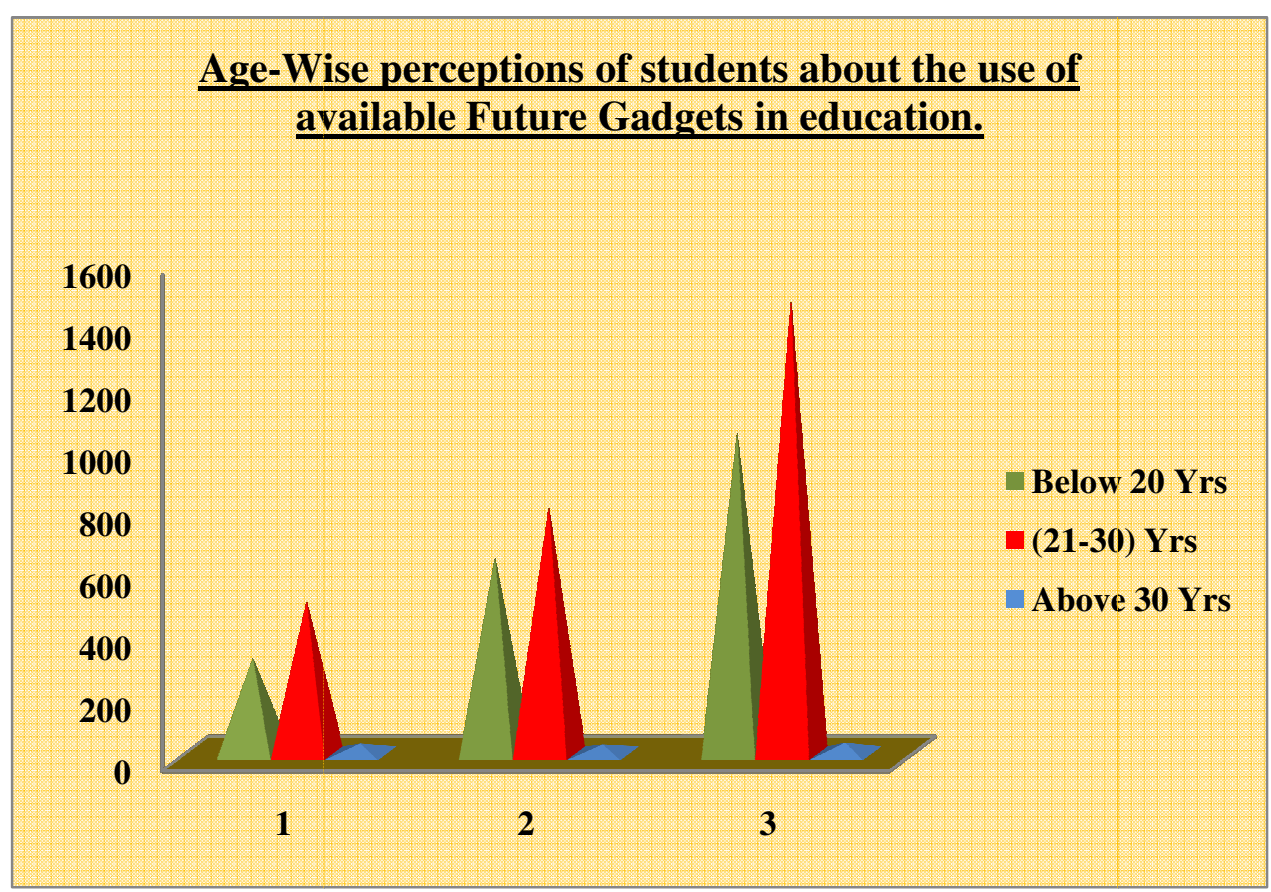

Table no-3

\begin{tabular}{|c|c|c|c|c|}
\hline \multirow{2}{*}{$\begin{array}{l}\text { Background } \\
\text { Variables }\end{array}$} & \multicolumn{3}{|c|}{ Stream-Wise (Learning) } & \multirow{2}{*}{ Total } \\
\hline & 1 (Least relevant) & 2(Relevant) & 3(Most Relevant) & \\
\hline $\begin{array}{l}\text { Higher Education } \\
\text { Engineering }\end{array}$ & $\begin{array}{c}684 \\
702.10 \\
(0.47)\end{array}$ & $\begin{array}{c}1242 \\
1232.50 \\
(0.07)\end{array}$ & $\begin{array}{c}2154 \\
2145.40 \\
(0.03)\end{array}$ & 4080 \\
\hline $\begin{array}{l}\text { Higher Education } \\
\text { Science }\end{array}$ & $\begin{array}{c}54 \\
49.56 \\
(0.40)\end{array}$ & $\begin{array}{c}77 \\
87.00 \\
(1.15)\end{array}$ & $\begin{array}{c}157 \\
151.44 \\
(0.20)\end{array}$ & 288 \\
\hline \multirow[t]{2}{*}{$\begin{array}{l}\text { Doctorate } \\
\text { Engineering } \\
\text { /I.T./Computer }\end{array}$} & $\begin{array}{c}88 \\
74.34 \\
(2.51)\end{array}$ & $\begin{array}{c}131 \\
130.50 \\
(0.00)\end{array}$ & $\begin{array}{c}213 \\
227.16 \\
(0.88)\end{array}$ & 432 \\
\hline & 826 & 1450 & 2524 & 4800 \\
\hline
\end{tabular}

$$
\chi^{2}=5.720, \quad \text { df }=4, \quad \chi^{2} / \mathrm{df}=1.43, \quad \mathbf{P}\left(\chi^{2}>5.720\right)=0.2210
$$


Operations Research and Applications : An International Journal (ORAJ), Vol.2, No.4, November 2015

* Expected values are displayed in italics; Individual $\chi^{2}$ values are displayed in (parentheses)

Graph-3:- Test of Independence (Chi-Square) - Educational-Qualification Wise perceptions of students about the use of available Future Gadgets in education.

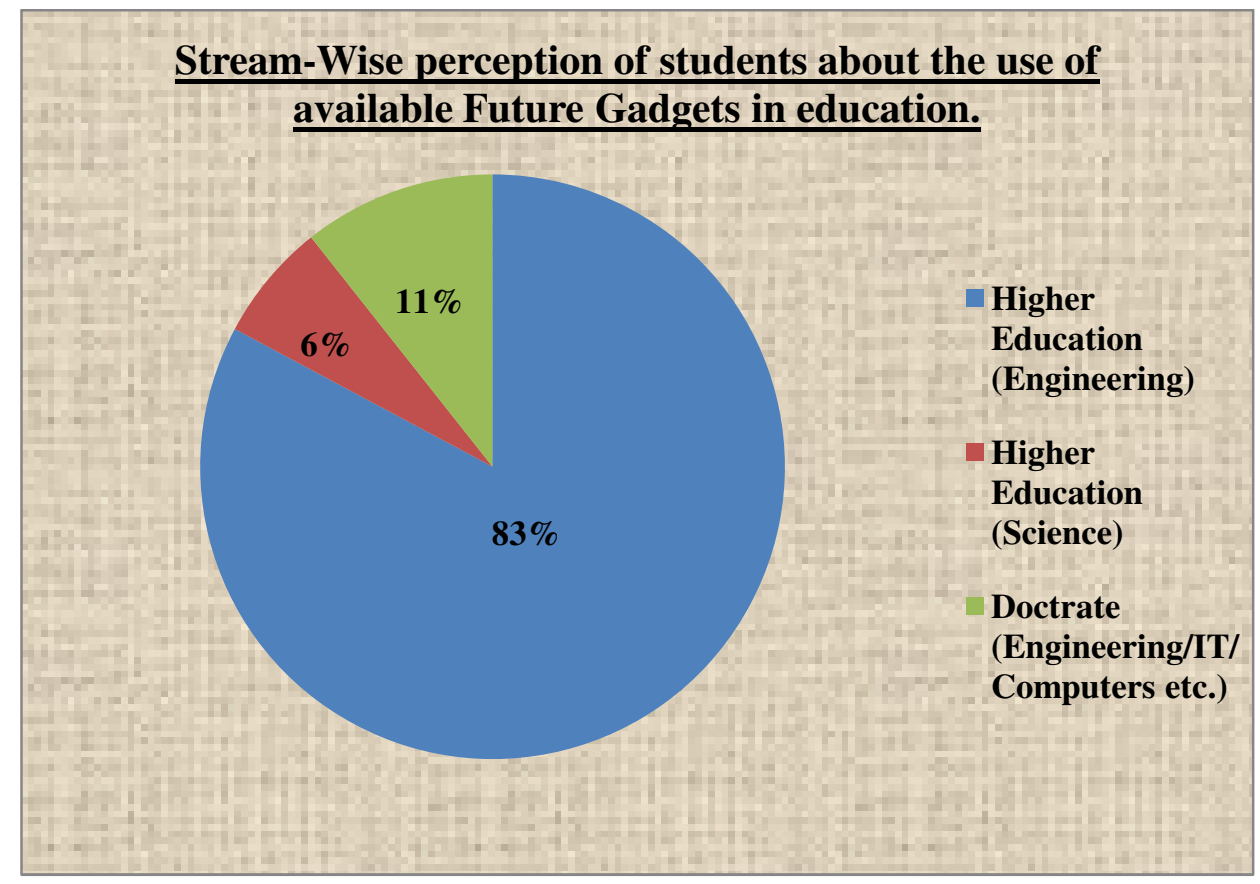

Table no-4

\begin{tabular}{|c|c|c|c|c|}
\hline \multirow{2}{*}{$\begin{array}{c}\text { Background } \\
\text { Variables }\end{array}$} & \multicolumn{3}{|c|}{ Qualification-Wise (Learning) } & \multirow{2}{*}{ Total } \\
\hline & 1(Least relevant) & 2(Relevant) & 3(Most Relevant) & \\
\hline Bachelor's Level & $\begin{array}{c}323 \\
363.44 \\
(4.50)\end{array}$ & $\begin{array}{c}668 \\
638.00 \\
(1.41)\end{array}$ & $\begin{array}{c}1121 \\
1110.56 \\
(0.10)\end{array}$ & 2112 \\
\hline Master's Level & $\begin{array}{c}418 \\
392.35 \\
(1.68)\end{array}$ & $\begin{array}{c}655 \\
688.75 \\
(1.65)\end{array}$ & $\begin{array}{c}1207 \\
1198.90 \\
(0.05)\end{array}$ & 2280 \\
\hline Doctorate Level & $\begin{array}{c}85 \\
70.21 \\
(3.12)\end{array}$ & $\begin{array}{c}127 \\
123.25 \\
(0.11)\end{array}$ & $\begin{array}{c}196 \\
214.54 \\
(1.60)\end{array}$ & 408 \\
\hline Total & 826 & 1450 & 2524 & 4800 \\
\hline
\end{tabular}

$$
\chi^{2}=14.226, \quad \text { df }=4, \quad \chi^{2} / \mathrm{df}=3.56, \quad \mathrm{P}\left(\chi^{2}>14.226\right)=0.0066
$$

* Expected values are displayed in italics 
Operations Research and Applications : An International Journal (ORAJ), Vol.2, No.4, November 2015

* Individual $\chi^{2}$ values are displayed in (parentheses)

Graph-4:- Test of Independence (Chi-Square) - Stream-Wise perceptions of students about the use of available Future Gadgets in education.

\section{Educational Qualification-Wise perceptions of students about the use of} available Future Gadgets in education.

Bachelor's Level Master's Level Doctorate Level

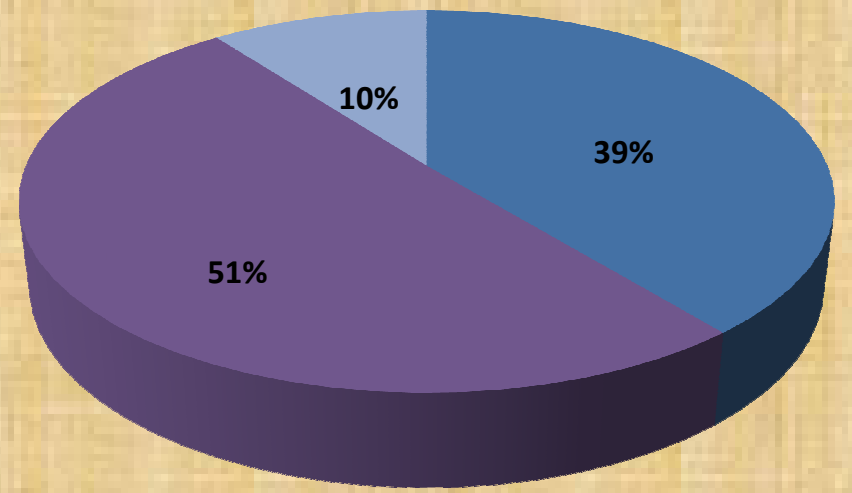

\section{LIMITATIONS}

$>$ Due to shortage of time duration, it was not able to standardize the tool and establishing reliability of the tool, so above results should be considered in the limitations of the tool.

$>$ The present study engaged only the students of professional and technical courses such as Engineering, Sciences, technology, I.T. / Computers, Animations etc. of Chandigarh region only. Thr social sciences students could also have been included in the research study.

$>$ The background variables like the medium of communication/instruction (Local, Regional or English level), and locality (rural/urban) could also have been included in the study.

$>$ The research could also have been conducted on the other stakeholders such as school level teacher, students, administrators, principals, educationists etc.

$>$ The provision of special education and inclusive education could also be a part of the study.

\section{CONCLUSiOnS}

The conclusion of the study is presented according to the analysis of data based on objectives and hypothesis. The objective-wise conclusions are given as below: 
Operations Research and Applications : An International Journal (ORAJ), Vol.2, No.4, November 2015

\section{To identify the future gadgets that can be used in education for students.}

It is possible to identify the future gadgets that can be used for educational purposes for teachers in teaching/instruction. The researcher investigated 234 available future gadgets that can be used for educational purposes in teaching/instruction domain.

2. To explore the educational utilization of the future gadgets that can be used in educational purpose.

It is possible to explore the educational uses of future gadgets for teacher-educators especially in teaching/instruction domains.

\section{To study the opinion of students about the use of future gadgets in education with respect to their background variables.}

The opinions of the teachers have been taken, in which most of the teachers have positive attitude towards the use of future gadgets in education. It may be because of their awareness and keen interest in the future gadgets that may effectively be used in teaching/instruction purposes thereby saving time, cost and energy with the availability of course content to the masses.

\section{To analyze the perceptions of students about the use of future gadgets in education with respect to the gender.}

From the above analysis of the tools about the utilization of future gadgets in education, it has been found that about $16.59 \%$ male students and $23.03 \%$ of female students opined for the least relevancy of the future gadgets, $32.01 \%$ male students and $25.71 \%$ of female students have found that the future gadgets are of relevant use, and $51.68 \%$ male students and $51.25 \%$ of female students have found that future gadgets to be of the highly relevant in terms of their utilization in education with respect to gender.

\section{To analyze the perceptions of teacher educators about the use of future gadgets in education with respect to the age.}

The analysis about the opinions of student's towards the use of future gadgets revealed that the for students age group below 20 yrs (15.54\%), between age group (21-30) yrs (17.83\%), and above 30 yrs $(33.33 \%)$ the future gadgets are found to be of least relevant in terms of their usage. Similarly for age group below 20 yrs (32.01\%), between age group (21-30) yrs (28.91\%), and above 30 yrs $(30.20 \%)$ opined for the relevancy of future gadgets. The students belonging to age group below 20 yrs (52.43\%), between age group (21-30) yrs (53.25\%), and above 30 yrs $(36.45 \%)$ believed that future gadgets are of mode relevant in terms of their utilization with respect to the age group.

\section{To analyze the perceptions of students about the use of future gadgets in education with respect to the streams.}

The analysis of the results clearly depicted that the $16.76 \%, 30.44 \%$ and $52.79 \%$ students of having higher education in the field of Engineering, Computers, I.T. have found future gadgets to be of least relevant, relevant and most relevant respectively in terms of educational utilization. The higher education Science students found that the use of future gadgets is $18.75 \%$ (least 
Operations Research and Applications : An International Journal (ORAJ), Vol.2, No.4, November 2015

relevant), $26.73 \%$ (relevant) and $54.51 \%$ (most relevant), whereas the students having doctorate Engineering, I.T., Computers degree opined $20.37 \%$ (least relevant), 30.32\% (relevant) and $49.30 \%$ (most relevant) about the utilization of future gadgets in terms of their educational qualifications.

\section{To analyze the perceptions of students about the use of future gadgets in education with respect to the educational qualifications.}

From the analysis about the perceptions of students towards future gadgets in education clearly depicted that the less number i.e. $15.29 \%, 31.62 \%$ and $53.07 \%$ of students having bachelor's educational qualifications have found that the future gadgets are of least relevant, relevant and most relevant respectively in terms of educational utilization. Moreover, some post-graduate students opined $18.33 \%$ (least relevant), $28.72 \%$ (relevant) and $52.93 \%$ (most relevant) about the utilization of future gadgets in education. Although, most of the students having doctorate degree depicted that the use of future gadgets is $20.83 \%$ (least relevant), $31.12 \%$ (relevant) and $48.03 \%$ (most relevant) with respect to their educational qualifications.

\section{To prepare the roadmap for the future gadgets that can be used in educational purposes.}

It is possible to prepare a roadmap for further implementation of future gadgets to be used for educational purposes.

\section{* Hypotheses Wise}

$>$ There is no significant difference in the perception of student's about the utilization of available future gadgets in education with respect to the gender.

$>$ There is significant difference in the perception of student's about the utilization of available future gadgets in education with respect to the age.

$>$ There is significant difference in the perception of student's about the utilization of available future gadgets in education with respect to the streams.

$>$ There is no significant difference in the perception among students about the utilization of available future gadgets in education with respect to the educational-qualifications.

\section{RECOMMENDATIONS}

According to Mizuko, Ito, (Irvine) "Connected learning is socially embedded, interest-driven, and oriented toward expanding educational, economic, or political opportunity. It is realized when a young person is able to pursue a personal interest or passion with the support of friends and caring adults, and is in turn able to link this learning and interest to academic achievement, career success, or civic engagement. Unlike efforts at educational change that focus on technology deployment or institutional reform, connected learning takes a networked approach to social change that aligns with our ecological perspective." Thus, in this competitive world technology plays a crucial role. It is the technology which fills the communication gap between us. Today the innovative latest technologies and devices such as $3 \mathrm{G}, 4 \mathrm{G}$ and even 5G's are generating millions of apps for interactive multimedia.

The time is at no more long when the future classroom will be equipped with all modern gadgets and devices. The students will try to explore knowledge through long cable wires and small chips. The students need to carry huge bags, Paper-Pen-Pencils or any stationary items. The whole 
Operations Research and Applications : An International Journal (ORAJ), Vol.2, No.4, November 2015

world is going to become globalised soon. The teachers need not to write whole thing on the blackboard/chalkboard but simply has to carry a small tablet, laptop or chip to teach the whole masses.

Thus it is not only our responsibility but the responsibility of all our society and stakeholders to give proper infrastructure, technical expertise and human-non human resources to the educational institutions.

\section{REFERENCES}

[1] Baker,T.A. and Torgesen, J.K. (1985). An evaluation of Computer Assisted Instruction in phonological awareness, which below average readers. J. of Education Computing Research 13L 89103.

[2] Bender A.K. Cunningham, D., Duffy, T.M., and Perry J.P. (1995). Theory into Practice: How do we link? In T.M. Duffy and D.H. Jonassen (Eds.) Constructivism and Technology of Instruction- A Conversation, Lawrence Erlbaum Associates, Hillsdale, NJ, pp. 17-34.

[3] Best, W.J. (1959). Research in Education: U.S.A.: Prentice Hall of India Inc. Englewood Cliffs, P31.

[4] Cennamo S. Katherine \& Ross D. John (2010). Technology Integration for Meaningful Classroom Use. Wadsworth Cengage Learning, Nelson Education Ltd, U.S.A.ISBN- 13:978-0-495-83410-6.

[5] Chester, H.W. (Ed) (1960). Encyclopedia of educational research (3 rd ed). New York: The McMillian Co.

[6] Cuban, L., Kirkpatrick, H., \& Peck, C. (2001). High access and low use of technologies in high school classrooms: Explaining an apparent paradox, American Educational Research Journal, 38(4), 813-834.

[7] Deighton, Lee C. (1971). Encyclopedia of Educational Research. U.S.A.: The McMillian Company and the Free Press.

[8] Desai, R.H.: A Study of Effectiveness of Programmed Learning Strategy in Teaching of Physics in Eleventh Grade. Ph.D. (Edu.), Bombay University, 1986.

[9] Fullan, M. (2001). The new meaning of educational change (3rd ed.). New York, NY: Teachers College Press.Information on the WorLD programme is taken from the World Links for Development Website: http://www.worldbank.org/worldlinks/english/html/backgrnd.html. May 131999.

[10] Gagene, R.M. (1985). The conditions of learning and theory of instruction (4th Ed.). New York: Holt, Rinehart and Winston.

[11] Gopal K. Kanji, Abdul Malek \& Bin A. Tambi (1999) Total quality management in UK higher education institutions, Total Quality Management, 10:1,129-153, doi. http://dx.doi.org/10.1080/0954412998126.

[12] Green, Diana, Ed. (1994). What Is Quality in Higher Education? SHRE, Open University Press, U.S.A.

[13] Guilford, J.P. and Fruchter, Benjamin (1981). Fundamental statistics in psychology and education. New Delhi: McGraw Hill International Book Company. http://www.qualityresearchinternational.com/glossary/transformation.htm.

[14] IMRB. (2001). Evaluating the implementation of the Intel 'Teach to the Future' Programme.

[15] Mark, Pegrum., Christine, Howitt., \& Michelle, Stripe.(2013). Learning to take the Tablet : How PreService teachers use iPads to facilitate their Learning. Australasian Journal of Educational Technology, 29(4). 2013, 464-479. Retrieved August 09, 2014 from http://www.ascilite.org.au/ajet/submission/index.php/AJET/article/download/.../604.

[16] Mumtaz, S. (2000). Factors affecting teachers' use of information and communications technology: A review of the literature. Journal of Information Technology for Teacher Education, 9(3), 319-342.

[17] No Child Left Behind Act of 2001, Pub L. No. 107-1105. (2001).Washington, DC: U. S. Congress.

[18] Reigeluty, C.M. (1999). Instructional design theories and models. A new paradigm of instructional theory (Vol. II). Mahawah, NJ: Lawrence Erlbaum Associates. 
Operations Research and Applications : An International Journal (ORAJ), Vol.2, No.4, November 2015

[19] Roward, C. (2000). Teacher use of computers and the Internet in public schools. Washington, DC: National Center for Education Statistics. Retrieved on October 6, 2008, from http://nces.ed.gov/pubs2000/2000090.pdf

[20] Salend J. Spencer (2009). Classroom Testing and Assessment for All Students. Corwin Sage Publications. U.S.A. ISBN- 978-1-4129-6643-6.

[21] Sansanwal, D.N.: Jerk Technology. Journal of Indian Education, Vol. XXVI, No. 1, 2000, pp 17-22.

[22] Schiffman, S.S. (1995). Instructional systems design: Five views of the field. In G.J. Anglin (Ed.), Instructional technology: Past, present and future. Englewood, CO: Libraries Unlimited, Inc.

[23] Smerdon, B., Cronen, S., Lanahan, L., Anderson, J., Iannotti, N. \& Angeles, J.(2000). Teachers' tools for the 21 st century: A report on teachers' use of technology. Washington, D.C.: National Center for Education Statistics, U.S. Department of Education.

[24] Van Dall, V., Reistsma (2000). "Computer-Assisted learning to Read and Spell: Results from Two Pilot Studies. "Journal of Research in Reading, 37, pp 22-31.

[25] Vannatta, R. A., \& Fordham, N. (2004). Teacher dispositions as predictors of classroom technology use. Journal of Research on Technology in Education, 36(3), 253-271.

[26] Wenglinsky, Harold (1998). Does it compute? The Relationship between educational Technology and Students Achievement in Mathematics, Educational Testing Service; Princeton, New Jersey.

\section{AUTHOR'S DETAILS}

\section{$>$ Ms. Sushma Rani. M.Sc. (Electronic Science), M.Ed., M.Phill. (Education), UGC-SRF (Senior Research Fellow), Ph.D. (Education)- Pursuing.}

Place and Date of Birth: Lucknow, India \& 01/08/1981

Educational Background: Presently as a UGC- Senior Research Fellow (UGCSRF) Department of Education, Banasthali University pursuing Ph.D. (Education).Also awarded UGC-Junior Research Fellow (UGC-JRF)Education, Dec-2011, Master of Philosophy (M.Phill) in Education, Kurukshetra University, Haryana, India, 2007, Master of Education (M.Ed.) from Department of Education, Kurukshetra University, Haryana, India, 2006, Master of Electronic Science (M.Sc.) from Department of Electronic Sciences, Kurukshetra University, Haryana,2004, Bachelors of Electronic Sciences (B.Sc.) from S.D. College Ambala Cantt, Haryana, India, 2001.

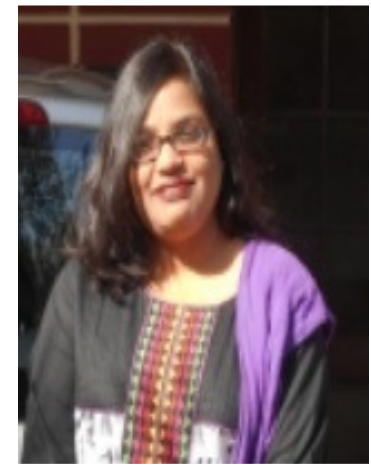

She has worked as an Assistant Protessor in the varıous selt-tınancing B.Ed./M.Ed. colleges, affiliated to Kurukshetra University (Haryana), since year 2006-2013. Her specialization for teaching B.Ed. /M.Ed. classes are Teaching of Physical Sciences, Educational Technology, ICT and Computer Education. After qualifying her UGC-JRF, she has been enrolled as a Junior Research Fellow (UGC-JRF) - Education, Department of Education, Banasthali University, Jaipur (Tonk), Rajasthan since 2013. Her field area of research is Educational Technology, ICT (Information \& Communication Technology), and Computer Education. Her previous area of interest were ICT (Information \& Communication Technology) and CAI (Computer Assisted Instruction), CDROM-Based learning.

\section{Publications:}

$>$ Ms. Suhsma Rani. has published online publishing- "Professional development of teachers through the use of ICT resources and gadgets", in GIAPS, International Journal of Students Research in Technology and Management. eISSN -2321-2543, Impact Factor- 0.998. Vol.3 (01).

$>$ Ms. Sushma Rani has published research paper in an International Journal of "Acme Intellects of Management", on the topic entitled "Status of ICT and CAI based learning among the students of 
Operations Research and Applications : An International Journal (ORAJ), Vol.2, No.4, November 2015

Govt. and Non- Govt. schools.” Vol. 3, No. 3, July 2013. ISSN - 2320 -2939 (Print), ISSN- 23202793 (Online) - Quarterly Journal.

$>$ Ms. Suhsma Rani. has published a research paper in "International Journal for Scientific Research and Development," IJSRD International Journal on the topic "Trends in Studies related to the Use of Future Gadgets in Education". Vol. 3, Issue 2, April 2015. ISSN (Online) 23210613. Impact Factor- 1.82. PP. 102-108.

$>$ Ms. Suhsma Rani. has published a research paper in "International Journal of Innovation and Research in Educational Sciences," IJIRES International Journal on the topic "Perception of Students about the Use of Future Gadgets in Education". Vol. 2, Issue 3, May 2015. ISSN23495219.PP-175-181.

$>$ Ms. Suhsma Rani. has published a research paper in "Parepakhya- A Research Journal of New Thoughts," Journal (A Quarterly Journal) on the topic "Comparative effectiveness of CD-ROM based learning and conventional method o of teaching on the academic achievement of B.Ed. students in Computer Education." Vol. XIII, 2014. ISSN: - 2278-0602 (PP-49).

\section{Chapters in a Book}

> Ms Sushma Rani has published a chapter "Teacher Education-Issues \& Challenges" in a book entitled "Empowering Teacher Educators for Quality Teacher Education", SAAD Publications. PP-75.

> Ms Sushma Rani has published a chapter "Yoga Practices in Education- To reduce Burden \& Social Stress" in a book entitled "Futuristic Trends in Physical Education", Twenty First Century Publications, Vol. 1. PP-401-406. ISBN: - 978-93-8014462-7.

> Ms Sushma Rani has published a chapter "Best ICT practices in classrooms" in a book entitled "IQAC-A Pivot of Educational Spokes", Twenty First Century Publications. PP- 240-248. ISBN: 978-93-80144-82-5.

\section{Memberships}

$>$ Ms. Sushma Rani is a life-time member of CTE (Council of Teacher Education) \& IATE (Indian Association of Teacher Educator). 